\title{
As Estruturas Antropológicas do Imaginário de Gilbert Durand em Cinco Pinturas de Arcimboldo ${ }^{1}$
}

\section{The Antropological Structures of the Imaginary by Gilbert Durand on Five Arcimboldo's Paintings}

\author{
Sandra Iris Sobrera Abella ${ }^{2}$, Rafael Raffaelli ${ }^{3}$
}

\begin{abstract}
Resumo
Trata-se do recorte de uma pesquisa que visa investigar o imaginário na obra de Giuseppe Arcimboldo, artista italiano do século XVI que vem chamando a atenção atualmente em virtude de suas ilusões de ótica. Neste trabalho, o objetivo é estabelecer reflexões sobre cinco de suas obras, com base nas estruturas do imaginário conforme Gilbert Durand. Foi possível identificar a presença de imagens referentes ao regime diurno - representando o poder paternal e aspectos de racionalidade e ascensão - e também ao regime noturno - remetendo aos ciclos da natureza, ao materno e ao eterno feminino, à descida e à profundidade, com destaque para a simbologia vegetal e alimentar. Tais simbologias, consoantes com o imaginário renascentista, reaparecem num momento em que predomina a simbologia diurna e a leitura imagética possui características diferenciadas, embora o imaginário transcenda limites temporais e espaciais.
\end{abstract}

Palavras-chave: Arcimboldo. Imaginário. Simbólico. Leitura de imagens. Pintura.

\section{Abstract}

This is the part of a study aimed at investigating the imagery in the work of Giuseppe Arcimboldo, a sixteenth-century Italian artist who is catching people's attention, today, because of his optical illusions. In this work, the objective is to provide reflections on five of his works based on the structures of the imaginary, according to Gilbert Durand. It was possible to identify the presence of images related to the daytime regime, which represents the paternal responsibility, aspects of rationality and rise. And also, the nocturnal regime that refers to the cycles of nature, the mother, the eternal feminine, the descent and depth, with emphasis on the vegetal and nutritive symbolism. Such symbols, which are consonant with the Renaissance imaginary, reappear at a time when it is dominant the daytime symbolism and the imagery reading has distinctive characteristics, although the imaginary transcends spatial and time limits.

\footnotetext{
${ }^{1}$ Este artigo é uma versão ampliada e aprimorada do texto "Considerações acerca do imaginário em pinturas de Arcimboldo a partir do referencial teórico e metodológico de Gilbert Durand", apresentado no IV Colóquio Internacional Imaginário, Cultura e Educação e publicado nos anais do evento, realizado em Niterói/RJ, 2011.

${ }^{2}$ Graduada em Psicologia, Mestre em Psicologia e Doutoranda do Programa de Pós-Graduação Interdisciplinar em Ciências Humanas da UFSC. E-mail para contato: sobrera@hotmail.com.

${ }^{3}$ Professor do Departamento do Curso de Graduação em Psicologia, do Departamento do Curso de Graduação em Cinema e do Programa de Pós-Graduação Interdisciplinar em Ciências Humanas, da UFSC. E-mail para contato: raffaelli.rafael@gmail.com.
}

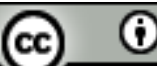

Esta obra foi licenciada com uma Licença Creative Commons - Atribuição 3.0 Não Adaptada 
Key words: Arcimboldo. Imaginary. Symbolic. Reading of images. Painting.

\section{Introdução}

Este trabalho consiste em uma leitura de obras de Giuseppe Arcimboldo, artista italiano do século XVI, realizada à luz da concepção durandiana de estruturas do imaginário, analisando a significação dessas imagens a partir da identificação dos regimes, estruturas e esquemas aos quais os elementos que formam seus retratos podem ser relacionados, bem como narrativas míticas que remetem a significados arquetípicos. Tal abordagem permite um maior aprofundamento na análise da obra ao relacionar seus elementos componentes aos significados correspondentes em diversas culturas de variadas temporalidades e localizações geográficas.

Esta análise faz parte de uma pesquisa de doutorado interdisciplinar em ciências humanas em andamento, a qual investiga o simbólico e o imaginário na obra do artista citado, o qual, durante sua estada na corte imperial em Praga, sob a proteção e incentivo do imperador Rodolfo II, pintou as suas famosas cabeças "humanas" compostas por seres e objetos diversos.

Apesar de ter sido um artista do século XVI, localizado no início da modernidade - ou da pré-modernidade, segundo alguns autores - em suas obras pode-se claramente identificar a forma de representar seja objetos, flores, frutos, legumes, verduras ou outros alimentos, e também crianças, como a dos artistas renascentistas, extremamente detalhados, demostrando um domínio virtuosístico da técnica pictórica. Ao mesmo tempo, costuma chamar a atenção o fato de que, inventivamente e até mesmo surpreendentemente, tais objetos podem ser também percebidos formando uma face humana nada convencional na forma de representação, parecendo diferente dos artistas de sua época, com exceção da informação que se tem da existência de imitadores que pintavam à maneira desse artista.

O foco de análise sobre a obra desse artista, criador das referidas imagens compostas, destaca o imaginário, tendo em vista o fato de que o uso da imaginação é proeminente no modo como os elementos naturais representados são rearranjados de formas inusitadas. Sendo pertinente também destacar a atemporalidade do imaginário ao qual tais obras remetem, não se restringindo a uma determinada época, considerando que, após um extenso período de esquecimento e 
depreciação, as obras do referido artista tornaram-se famosas, ocupando um lugar privilegiado na cultura visual atual, em virtude do interesse despertado por suas ilusões de ótica e jogos visuais (KAUFFMANN, 2009).

\section{Metodologia}

Como mencionado anteriormente, este trabalho tem como objetivo identificar arquétipos e narrativas míticas presentes na linguagem pictórica de obras de Arcimboldo selecionadas para a análise, com embasamento no referencial teórico de Gilbert Durand e suas estruturas do imaginário. Para tanto, foram selecionadas cinco obras de Arcimboldo: a série "Os Quatro Elementos" ("Fogo", "Terra”, "Ar" e "Água") (figuras 1 a 4) e "Vertumnus" (um retrato do imperador Rodolfo II) (figura 5). A seleção foi realizada em virtude de tais obras apresentarem elementos diversificados, constando de animais aéreos, terrestres e aquáticos, bem como objetos símbolos de riqueza a partir de minerais, e elementos botânicos: flores, frutos e legumes, permitindo assim abranger uma diversidade de símbolos interessantes para uma análise realizada a partir das estruturas do imaginário conforme Gilbert Durand. Além disso, tal seleção de imagens foi necessária para o presente trabalho, visando não estender demasiadamente a análise.

A análise, que consistiu em uma aproximação às obras e não em uma análise definitiva, partiu dos elementos presentes nas próprias obras, permitindo identificar símbolos concernentes às estruturas do imaginário conforme Gilbert Durand, seguindo o seu método de convergência simbólica, numa abordagem interdisciplinar de base antropológica. É relevante também assinalar que os mitos e significados atribuídos por diferentes culturas mencionados a seguir procedem de Durand (2002). A leitura dessas obras, partindo de significados compartilhados e presentes nas mais diversas culturas, pressupõe a existência de significados presentes em diferentes grupos culturais, que por transcender as apropriações singulares, permite a comunicação pelas imagens. 


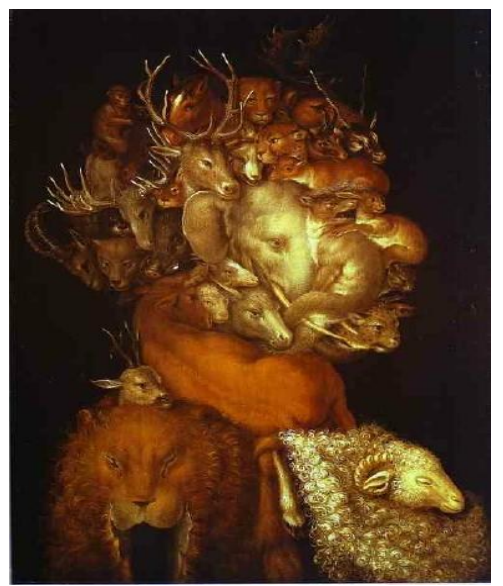

Figura 1 - “Terra”, c.1570.

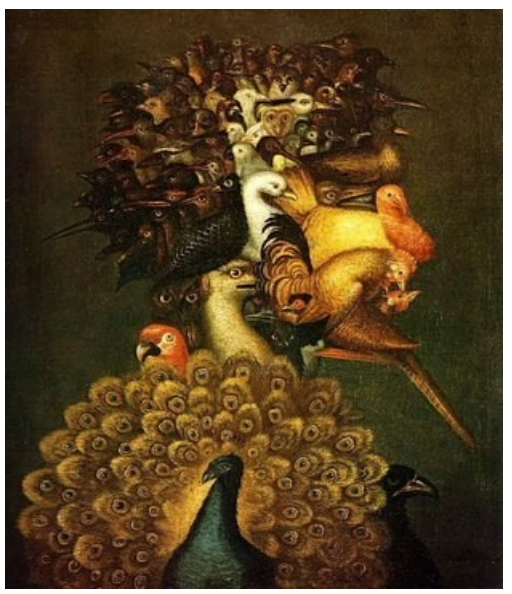

Figura 3 - "Ar", não datado.

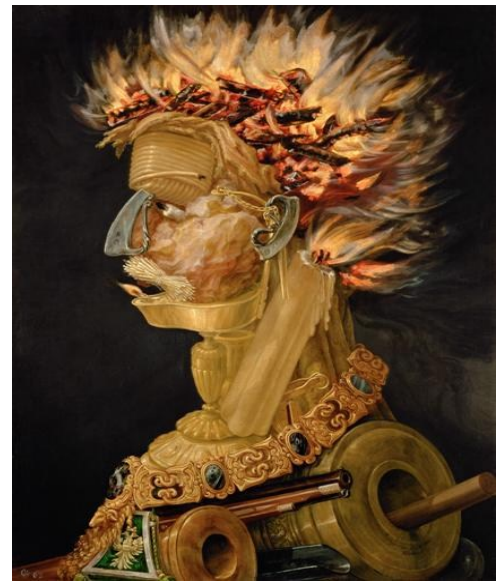

Figura 2 - "Fogo", 1566.

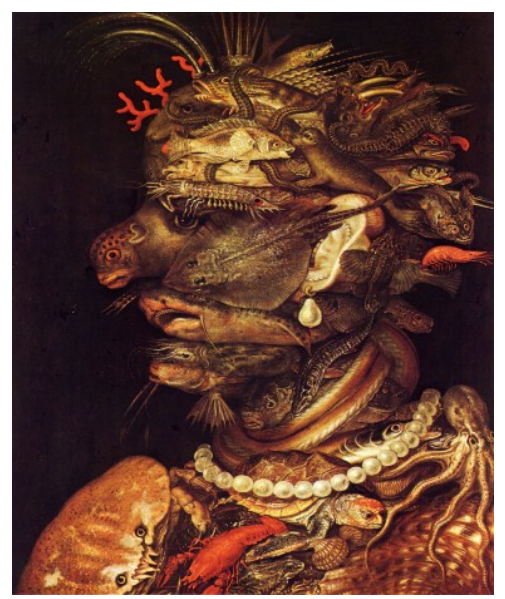

Figura 4 - “Água”, 1566.

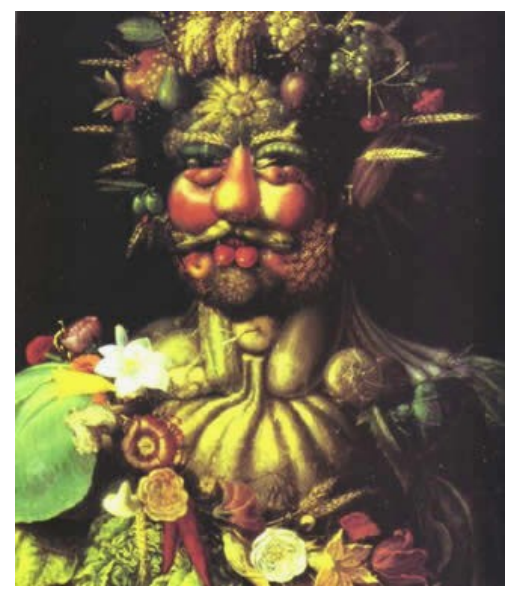

Figura 5 - "Vertumnus", c. $1590^{4}$.

\footnotetext{
${ }^{4}$ A fonte de todas essas reproduções foi a coleção completa das obras de Arcimboldo, exposta on-
} 


\section{Considerações teóricas}

\subsection{Imagem e as estruturas simbólicas do imaginário}

Gilbert Durand (2002) construiu a sua abordagem ao imaginário partindo de sua apreensão e discordância quanto à desvalorização das imagens por perspectivas teóricas que enfatizam a consciência racional, em detrimento do aspecto da realidade que não pode ser explicado ou compreendido exclusivamente pela razão, como o inconsciente, a imaginação, a fantasia, os mitos e a subjetividade. Assim, podem-se compreender as imagens simbólicas como fazendo parte do imaginário, o qual, por sua vez, é concebido como o acervo de imagens da humanidade, mais especificamente como: "o conjunto das imagens e relações de imagens que constitui o capital pensado do homo sapiens (...), o grande denominador fundamental onde se vêm encontrar todas as criações do pensamento humano" (DURAND, 2002, p.18). Sendo que tal museu imaginário, que é simbólico, além de consistir uma mera coletânea de imagens, deve ir além disso, considerando a subjetividade e permitindo a implicação de uma coletividade, superando a fragmentação, e assim buscar "compor o complexo quadro das esperanças e temores de toda a humanidade, para que cada um se conheça e reconheça nela". (DURAND, 1968, p.134).

Durand (2004) também confere um lugar privilegiado para o mito, definido como resultante da combinação entre imagem e símbolo, destacando a importância vital dos mitos, os quais transmitem verdades importantes para a sociedade em narrativas repletas de simbolismo.

\footnotetext{
Entenderemos por mito um sistema dinâmico de símbolos, arquétipos e esquemas, sistema dinâmico que, sob o impulso de um esquema, tende a compor-se em narrativa. O mito é um esboço de racionalização, dado que utiliza o fio do discurso, no qual os símbolos se resolvem em palavras e os arquétipos em idéias. (DURAND, 2002, p.62-63).
}

O autor em questão enfatiza a imagem em seu aspecto simbólico, apontando para o seu aspecto analógico:

O analogon que a imagem constitui não é nunca um signo arbitrariamente

line no site Web Gallery of Art (2011).

Cad. de Pesq. Interdisc. em Ci-s. Hum-s., Florianópolis, v.13, n.102, p.224-249 jan/jun 2012 
escolhido, é sempre intrinsecamente motivado, o que significa que é sempre símbolo. (DURAND, 2002, p.29 - grifo do autor).

Sua busca por uma nova forma de categorizar as imagens por meio de uma classificação estrutural não reducionista partiu também de sua insatisfação pelas categorizações existentes construídas com base em conhecimentos exteriores às imagens. Assim, Durand (2002) defende uma abordagem às imagens a partir da identificação de significados intrínsecos às próprias imagens, recorrentes em culturas de diversas localidades e temporalidades. Tais imagens são categorizadas em duas grandes estruturas denominadas de regimes diurno e noturno, as quais não são "agrupamentos rígidos de formas imutáveis" (DURAND, 2002, p.64), embora o regime diurno tenda a excluir o noturno, e a cultura ocidental tenha predominantemente enfatizado o primeiro. Embora no Regime Diurno ocorram antíteses que buscam predominar em detrimento de simbologias ditas noturnas, o Regime Noturno tolera os aspectos do imaginário categorizados como diurnos. Sendo os símbolos relacionados ao regime diurno conforme a significação predominante remeter mais a ideias de ascensão-heroísmo-poder-iluminação-razão, ou ao regime noturno para associações com descida-engolimento-trevas-intimidadeciclos, evidenciando uma concepção dinâmica dessas estruturas.

Assim, as imagens que podem ser compreendidas como pertencentes ao Regime Diurno representam ideias como verticalidade, ascensão, heroísmo, iluminação, poder paterno, masculinidade, racionalidade, ação, agressividade, dominação, objetividade, exibição, liberdade. Assim, conforme as ideias de Gilbert Durand, o aspecto diurno do imaginário é caracterizado por tais ideias que remetem a clareza, razão e objetividade, dicotomizando com o que é excluído dessas denominações. Sendo que esse regime do imaginário costuma aparecer representado por símbolos de purificação, desfeminização, separação, mais especificamente por meio da representação de: cabeças, dentes, céu, fogo, rei, guerreiro, cavalo, pássaros, animais ferozes - principalmente lobo e leão -, entre outros.

No Regime Noturno, por sua vez, as imagens são concernentes a ideias de descida, trevas, profundidade, o materno e eterno feminino, nutrição, refúgio, repouso, intimidade, transformação, regeneração, eterno retorno, devir. Sendo que o aspecto noturno do imaginário é caracterizado pela subjetividade, o feminino, obscuridade, representado muitas vezes pelas seguintes imagens: noite, sombras, 
monstros, abismo, águas profundas, serpentes, ouroboros, natureza, terra, alimentos, vegetais, flores, árvores, grãos, crustáceos, répteis, lagartos, batráquios, peixes, cordeiro, entre outros.

Entre as imagens apresentadas e discutidas por Durand (2002), foram citadas nos dois parágrafos anteriores, assim como serão consideradas com um pouco mais de detalhes a seguir, aquelas que podem ser identificadas nas obras de Arcimboldo, para fundamentar a análise.

\subsection{Algumas considerações sobre os simbolismos diurnos}

A cabeça, como elemento anatômico pode remeter ao que designa literalmente, ou seja, a parte do corpo superior em relação às demais, onde o cérebro se situa, indicando assim uma ideia de verticalidade e ascensão. Relacionada com a noção de microcosmo, a cabeça corresponde, pela sua localização no corpo e pelo próprio formato esférico, à "esfera celeste". Por esse motivo, simbolizando uma posição de liderança, a cabeça também pode ser interpretada como representando "o cabeça", ou seja, o líder, como é o caso do monarca de um reino, cuja autoridade deve ser obedecida pelos súditos. Neste sentido, representações da cabeça também podem simbolizar o patriarcalismo, evidenciando uma associação entre os simbolismos da ascensão e da monarquia, muitas vezes presentes na concepção do Deus celeste e na assimilação do monarca com soberanos históricos ou lendários, surgindo assim identificações com a imagem do herói, muitas vezes associando o rei com alguma divindade.

Com relação a essa última associação, o referido autor assinala que "dessa assimilação do céu ao monarca derivariam todas as filiações heróicas dos 'filhos do céu' e do sol." (DURAND, 2002, p.138). Muitas vezes esse simbolismo do monarca celestial não é solitário e nem dessexualizado, mantendo uma relação muito próxima com a terra e com suas riquezas materiais: "Esse simbolismo, ao dramatizar-se, metamorfosear-se-á no do Esposo celeste, companheiro fecundador da deusa mãe, e pouco a pouco os atributos da paternidade, da soberania e da virilidade confundirse-ão." (DURAND, 2002, p.138).

Assim, compreendendo a cabeça como simbolizando o monarca a partir de diferentes culturas, o mesmo é considerado um líder completo, enfatizando o uso dirigido da razão, considerado autoridade indiscutível e que deve ser obedecida 
pelos seus súditos. Portanto, Durand (2002) aponta para uma relação entre os simbolismos de ascensão e de monarquia, mostrando uma concepção de dominação do universo a partir da contemplação do alto.

\footnotetext{
O monarca é então ao mesmo tempo mago inspirado, com prerrogativas ascensionais, soberano jurista e ordenador monárquico do grupo, e acrescentaremos que não se podem separar destas duas funções os atributos executivos e guerreiros (DURAND, 2002, p.140).
}

Com base em indícios de pesquisas antropológicas, pode-se pensar sobre a simbologia da cabeça remetendo aos cultos ancestrais ao crânio (DURAND, 2002), encontrados em diferentes culturas anteriores e em localidades muitas vezes distanciadas geograficamente. Tal prática decorre da interpretação da cabeça como "potência microcósmica", ou seja, o "centro e princípio de vida, de força física e psíquica, e também receptáculo do espírito" (DURAND, 2002, p.142), do que se conclui que "o culto dos crânios seria então a primeira manifestação religiosa do psiquismo humano" (DURAND, 2002, p.142), ou seja, de valorização da consciência.

Ainda direcionando a atenção para a cabeça, pode-se pensar também nas simbologias dos olhos referindo à contemplação e ao julgamento moral. Sendo que os olhos muitas vezes são imaginados como símbolo de consciência, e Durand (2002, p.151-152) afirma também que "olho e olhar estão sempre ligados à transcendência, como constatam a mitologia universal e a psicanálise." Nesse sentido, apesar de evidentemente o conceito de superego ser inexistente à época de Arcimboldo, interessante a presença desse aspecto de julgamento na concepção do olhar de quem ocupa a posição hierárquica superior, como na seguinte afirmação de Durand (2002, p.152 - grifo do autor): "O superego é, antes de tudo, o olho do Pai e, mais tarde, o olho do rei, o olho de Deus, em virtude da ligação profunda estabelecida no patriarcalismo entre as autoridades paterna e política e o imperativo moral".

Outro elemento diurno presente na cabeça consiste na boca dentada, simbolizando crueldade e uma associação com animalidade. Assim, considerando esse aspecto selvagem da agressividade por parte do animal feroz, este costuma ser representado, muitas vezes, como "o que agita, o que foge e que não podemos apanhar, mas é também o que devora, o que rói” (DURAND, 2002, p.90). Por uma transferência de sentido do animal para o humano, 
(...) a boca (...) passa a simbolizar toda a animalidade, que se torna o arquétipo devorador dos símbolos que vamos examinar. Reparemos bem num aspecto essencial deste simbolismo: trata-se exclusivamente da boca armada com dentes acerados, pronta a triturar e morder, e não da simples boca que engole e que chupa que (...) é a exata inversão do presente arquétipo (DURAND, 2002, p. 84) ${ }^{5}$.

Entre os diversos animais representados nesse sentido de terrificante e assustador, e sua decorrente associação com o medo, a dor e o sadismo, destacamse a significação muitas vezes atribuídas ao lobo, e transferida diversas vezes também a outros animais com um sentido semelhante, como no caso do cão, do tigre e do leão (DURAND, 2002).

\begin{abstract}
Para a imaginação ocidental, o lobo é o animal feroz por excelência. Temido por toda a Antigüidade e pela Idade Média, volta aos tempos modernos (...) constitui o equivalente mítico e invernal das cobras do mar estivais. O lobo é ainda no século XX um símbolo infantil de medo pânico, de ameaça, de punição. (...). Num pensamento mais evoluído, o lobo é assimilado aos deuses da morte e aos gênios infernais (DURAND, 2002, p.86).
\end{abstract}

Ainda com relação à associação das bocas dentadas com animalidade, uma significação possível é a de tempo destruidor que conduz inevitavelmente à morte e representa "terror diante da mudança da morte devoradora" (DURAND, 2002, p.89).

Uma outra significação referente à simbologia dos dentes e da mordedura, consiste na associação com a alquimia (DURAND, 2002, p.84) e suas noções de "fervilhar anárquico" e "atacar" em que a "hostilidade fervilhante de lobos e de leões devoradores, existe paralelamente à doce química da afinidade e das 'Núpcias Químicas"' (DURAND, 2002, p.84).

Também como símbolo de poder, pode-se mencionar os chifres nas cabeças de animais sugerindo a ideia de potência também pelo fato de que podem servir como arma poderosa para o ataque, remetendo portanto à agressividade: "Na anatomia animal, é o chifre, imputrescível e cuja forma oblonga é diretamente sugestiva, que vai simbolizar excelentemente a potência viril, tanto mais que são os machos que têm chifres" (DURAND, 2002, p.142). O autor em questão assinala ainda uma relação entre monarca e chifres, constituindo uma simbologia de poder:

\footnotetext{
${ }^{5}$ Pois enquanto o primeiro simbolismo pertence ao regime diurno das imagens, o segundo pertence ao noturno.
} 
Nesta conjunção dos chifres animais e do chefe político ou religioso descobrimos um processo de anexação da potência por apropriação mágica dos objetos simbólicos. O chifre, o massacre do bovídeo ou do cervídeo é troféu, quer dizer, exaltação e apropriação da força (DURAND, 2002, p.143).

Portanto, no contexto da caça, o poder pode ser exemplificado pela cabeça do animal caçado exibido como um troféu, símbolo de heroísmo e do poder do animal transferido para o seu caçador como por uma apropriação mágica. Assim, esse aspecto da caça como resultado do desafio ao perigo, como uma proeza da qual resulta o sentido do heroísmo: "nem sequer é a perseguição que vale mais que a lebre atrás de que se vai, mas o sentido do feito, da proeza" (DURAND, 2002, p.143). A caça como troféu simboliza virilidade e desfeminização ${ }^{6}$, ao matar uma parte da natureza, o animal: "O troféu totêmico ou emblemático não é mais que o resultado da captação, sempre perigosa, da potência do tabu, é a sua desfeminização, a sua desanimalização (...)" (DURAND, 2002, p.144).

Durand também assinala um simbolismo presente na caça associada à queda e à alimentação carnívora como pecado: "A queda é (...) simbolizada pela carne, a carne que se come, ou a carne sexual, unificadas uma e outra pelo grande tabu do sangue" (DURAND, 2002, p.118). Nesse mesmo sentido de desfeminização, em oposição à ideia da queda, no regime noturno das imagens, Durand (2002, p.145146) afirma que "os símbolos ascensionais aparecem-nos marcados pela preocupação da reconquista de uma potência perdida, de um tônus degradado pela queda".

Além de simbolizar poder nos diversos aspectos vistos acima, a cabeça também pode ser associada com o elemento fogo referindo-se ao intelecto e ao pensamento, remetendo a uma intelectualização do cosmos e à divindade como possuindo um aspecto ígneo. Sendo que fogo, por sua luz e chama, também representa poder e pode aparecer simbolizando a divindade, e a incineração aparece muitas vezes com um sentido de transcendência e imortalidade da alma. Entretanto, Durand (2002) aponta também para a ambiguidade do fogo, que tanto pode ser associado à espiritualidade, como à sexualidade e ao erotismo. Em uma

\footnotetext{
${ }^{6}$ Lembra-se aqui ao(à) leitor(a) que estas simbologias referentes ao masculino e ao feminino está fora das discussões feministas sobre gênero, atendo-se ao significado tradicional acerca dessas dicotomias, como apresentado e discutido por autores como Gilbert Durand (1968, 2002, 2004), Carl G. Jung $(1981,2005)$, James Hillman (1984), entre outros que se debruçam teoricamente sobre o simbólico e o imaginário em uma perspectiva arquetípica.
} 
simbolização que relaciona o fogo com o masculino: "O fogo é chama purificadora, mas também centro genital do lar patriarcal." (DURAND, 2002, p.174).

Outro aspecto relacionado com a ideia de ascensão é a purificação, a qual pode ser efetuada por meio dos elementos água, ar e fogo, sendo a terra considerada o elemento mais impuro, necessitando de uma operação alquímica para ser purificada, surgindo sob a forma de metal ou sal (DURAND, 2002).

\subsection{Algumas considerações sobre os simbolismos noturnos}

Em contraposição ao conjunto de imagens que acabou de ser apresentado, veiculando ideias de ascensão, claridade, intelecto e domínio, Durand também identificou imagens que podem ser agrupadas em um outro conjunto, transmitindo ideias de descida, obscuridade, intimidade e repouso, designadas por esse autor como imagens noturnas.

A própria ideia de símbolos noturnos representando os esquemas da descida e da intimidade permite remeter de início à noite como representação simbólica, enfatizando um aspecto geral sombrio, misterioso, caótico e até mesmo aterrorizante, associado a uma imaginação de trevas nefastas. Durand associa a esse simbolismo os sentimentos de abatimento, angústia e medo: "símbolo de um temor fundamental do risco natural, acompanhado de um sentimento de culpabilidade (...) pecado, revolta e julgamento, [remetendo ao] terror dos nossos antepassados diante da aproximação da noite" (DURAND, 2002, p.91).

Assim, as trevas são muitas vezes associadas a ameaças de possessão das almas pelo mal e às superstições, com uma ligação com a magia e a feitiçaria.

\footnotetext{
No folclore, a hora do fim do dia, ou a meia-noite sinistra, deixa numerosas marcas terrificantes: é a hora em que os animais maléficos e os monstros infernais se apoderam dos corpos e das almas. Esta imaginação das trevas nefastas parece ser um dado fundamental, opondo-se à imaginação da luz do dia. As trevas noturnas constituem o primeiro símbolo do tempo (...) (DURAND, 2002, p.91).
}

Durand (2002, p.92) afirma também que "as trevas são sempre caos e ranger de dentes", unindo assim a simbologia das trevas com o aspecto agressivo do regime diurno das imagens, e assimilando também as trevas à concepção de inferno (DURAND, 2002, p.92). 
Também referente ao imaginário do tenebroso, pode-se assinalar a imagem do monstro simbolizando totalização, representando pluralidade e abundância, enfatizando assim "o caráter maravilhoso do conjunto monstruoso" (DURAND, 2002, p.313):

O 'monstro' é, com efeito, símbolo da totalização, de recenseamento completo das possibilidades naturais, e deste ponto de vista todo o animal lunar, mesmo o mais humilde, é conjunto monstruoso. Pode-se dizer que todo o maravilhoso teratológico é maravilhoso totalizante e que essa totalidade simboliza sempre a potência fasta e nefasta do devir (DURAND, 2002, p.313).

Outra simbologia que se refere ao esquema da descida e intimidade e aos ciclos naturais consiste nos símbolos botânicos, com destaque para os grãos e a árvore, por sua total ou parcial ocultação sob a terra. Estando relacionadas nas imagens de vegetais também as ideias de fertilidade, abundância, transformação, transcendência e longevidade, no sentido de que “(...) o papel metamorfoseante do vegetal é, em muitos casos, o de prolongar ou sugerir o prolongamento da vida humana" (DURAND, 2002, p.342). Sendo que aqui, no regime noturno do imaginário, predomina uma concepção de temporalidade cíclica, visível nos vegetais, principalmente nas árvores, enfatizando o mito do eterno retorno e eufemizando assim a noção de fatalidade do destino.

O otimismo cíclico parece reforçado no arquétipo da árvore, porque a verticalidade da árvore orienta, de uma maneira irreversível, o devir, e humaniza-o de algum modo ao aproximá-lo da estação vertical significativa da espécie humana (...) (DURAND, 2002, p.338).

Em tal concepção cíclica, o destaque recai na árvore pela sua verticalidade, novamente relacionando aqui com o regime diurno das imagens, embora no regime noturno a verticalidade também esteja presente, mas em direção contrária. Nesse sentido, no regime noturno não se encontram oposições tão diferenciadas e excludentes do seu oposto como nas simbologias pertencentes ao regime diurno, como afirma Durand: "Todo símbolo ligado ao ciclo possui ao mesmo tempo a sua parte de trevas e a sua parte de luz." (DURAND, 2002, p.328). 
contra a qual o tempo não teve poder, com a qual o devir é cúmplice da majestade das ramagens e da beleza das florações (DURAND, 2002, p.342).

Portanto, muitas vezes é realizada uma correspondência entre a árvore e o ser humano, como explicitado também na seguinte passagem:

\begin{abstract}
Pela sua verticalidade, a árvore cósmica humaniza-se e torna-se símbolo do microcosmo vertical que é o homem (...). Numa outra passagem, a árvore é verdadeiramente totalidade psicofisiológica da individualidade humana: o tronco é a inteligência, as cavidades interiores os nervos sensitivos, os ramos as impressões, os frutos e as flores as boas e más ações. (...) (DURAND, 2002, p.342).
\end{abstract}

Durand aponta também um significado para a árvore imaginada como "árvore genealógica", trazendo transcendência ao ciclo vital, pois a vida se mantém por meio da descendência: “(...) na imaginação qualquer árvore é irrevogavelmente genealógica, indicativa de um sentido único do tempo e da história que se tornará cada vez mais difícil inverter" (DURAND, 2002, p.345).

Tais ideias de simbolismo cíclico, descida e intimidade também costumam ser representadas pela serpente, pelo fato de esta ser capaz de embrenhar-se sob a superfície da terra: "(...) a serpente é um animal que desaparece com facilidade nas fendas do solo, que desce aos infernos, e pela muda regenera-se a si mesmo" (DURAND, 2002, p.316).

Uma diferença entre ambos os símbolos refere à ameaça presente na serpente e ausente na inofensiva árvore que pode ser sacrificada: "a árvore não sacrifica e não implica nenhuma ameaça, é ela que é sacrificada, madeira queimada do sacrifício (...)" (DURAND, 2002, p.344).

Outra correspondência encontrada entre os simbolismos da serpente e dos vegetais refere-se às lendas em que propriedades curativas são atribuídas ao veneno da serpente, como na seguinte afirmação de Durand: "A serpente é, então, guardiã, ladra ou detentora da planta da vida, como nas lendas semíticas, e o simbolismo ofídico vai assim ligar-se ao simbolismo vegetal da farmacopéia" (DURAND, 2002, p.317). Além disso, muitas vezes a serpente é representada como guardiã do segredo da morte, e também como um animal mágico e iniciático, símbolo de transformação, sendo que a propriedade regenerativa da serpente contribui para que seja vista como um animal mágico, como também sua suposta relação com a morte e os mortos: 
(...) Vivendo debaixo da terra, a serpente não só recepta o espírito dos mortos, como também possui o segredo da morte e do tempo: senhora do futuro do mesmo modo que detentora do passado, é o animal mágico (DURAND, 2002, p.320).

E ainda com relação à morte, Durand assinala que a iniciação do herói requer que este seja capaz de destruir a serpente, sendo que tal ato é relativo à simbologia diurna:

A serpente tem, assim, um papel simbolicamente positivo no mito do herói vencedor da morte. Ela é não apenas obstáculo, enigma, mas sim o obstáculo que o destino deve ultrapassar, o enigma que o destino deve resolver (DURAND, 2002, p.320).

Todos esses aspectos mencionados evidenciam a multiplicidade de significados que lhe pode ser relacionada:

A serpente é um dos símbolos mais importantes da imaginação humana. (...). A mitologia universal põe em relevo a tenacidade e a polivalência do simbolismo ofídico. (...). Parece que a serpente (...) é um verdadeiro nó-devíboras arquetipológico e desliza para demasiadas significações diferentes, mesmo contraditórias. (...). A serpente é o triplo símbolo da transformação temporal, da fecundidade e, por fim, da perenidade ancestral (DURAND, 2002, p.316).

Entre as múltiplas possibilidades interpretativas, uma das principais consiste na visão da serpente como símbolo de fecundidade e de sexualidade ambígua:

\begin{abstract}
A segunda direção simbólica que pode tomar a imagem da serpente não passa de um desenvolvimento das potências de perenidade e regeneração contidas no esquema do retorno. A serpente é, com efeito, símbolo de fecundidade. Fecundidade totalizante e híbrida uma vez que é ao mesmo tempo animal feminino, dado que lunar, e também masculino, porque a sua forma oblonga e o seu caminhar [sic] sugerem a virilidade do pênis (...) (DURAND, 2002, p.318).
\end{abstract}

Nesse sentido da serpente como um animal hermafrodita assinala-se para a imagem do ouroboros, ou seja, da cobra mordendo a própria cauda, representando assim a imagem do tempo circular e do eterno recomeçar: “(...) o ouroboros ofídico aparece assim como grande símbolo da totalização dos contrários, do ritmo perpétuo das fases alternadamente negativas e positivas do devir cósmico" (DURAND, 2002, p.318 - grifo do autor). 
Tal imagem hermafrodita ou andrógina pode ser relacionada com a alquimia, a qual buscava completude na presença de ambos os gêneros em um único:

(...). A iconografia alquímica parece tirar uma lição filosófica da figura bissexuada: os elementos contrários pela cor ou pelo sexo são 'encadeados', 'ligados por uma cadeia', um ao outro, ou então cada face sexuada do hermafrodita é ligada por uma cadeia ao seu 'princípio astral', sol para o macho, lua para a mulher. É que o andrógino, microcosmo de um ciclo em que as fases se equilibram sem que nenhuma seja desvalorizada em relação à outra, é, no fundo, justamente um 'símbolo de união'. Ele é a díade por excelência, que põe uma tônica igual nas duas fases, nos dois tempos do ciclo (DURAND, 2002, p.292).

Em comparação com a serpente, que destrói o objeto a ser engolido ao triturá-lo, outro símbolo noturno consiste no peixe, o qual engole peixes menores sem destruí-los da mesma forma, e que "parece pôr a tônica no caráter involutivo e intimista do engolimento" (DURAND, 2002, p.216), considerando-se os múltiplos engolimentos. Sendo que o autor em questão, enfatizando a associação entre o peixe como um simbolismo de intimidade, acrescenta ainda que "o peixe é quase sempre significativo de uma reabilitação dos instintos primordiais" (DURAND, 2002, p.216).

(...). Sem esquecer que esse poder de redobramento [decorrente de múltiplos engolimentos], pela confusão do sentido passivo e ativo que implica, é, tal como a dupla negação, capacidade de inversão do sentido diurno das imagens. É essa inversão que vamos ver em funcionamento, metamorfoseando os grandes arquétipos do medo e transformando-os, como que do interior, por integração prudente dos valores benéficos (DURAND, 2002, p.217).

O simbolismo da intimidade, além de aparecer muitas vezes representado por peixes, com a já mencionada concepção de engolimento associada, também pode aparecer por meio da imagem de conchas, com sua simbologia de esconderijo, refúgio e repouso (DURAND, 2002).

Tais representações de natureza acabam sendo associadas com a ideia de eterno feminino e de maternidade, simbolizado no alimento primordial natural e nas metáforas digestivas, como os diversos aspectos alimentares descritos a seguir:

Muito freqüentemente, essa acentuação do caráter lactífero e alimentar da Deusa faz que o arquétipo da Mãe se anastomose com o da árvore ou da planta lactífera, como o Ficus religiosa ou o Ficus ruminalis. (...). É talvez por intermédio dessa imagem composta de leite e vegetação, figueira 'nutritiva' por excelência, já que além dos frutos sugere pelo seu suco o 
líquido alimentador primordial, ou por outras plantas nutritivas, como a tamareira, a vinha, o trigo ou o milho, que se pode explicar a freqüente colusão dos símbolos alimentares e dos recipientes culinários com os arquétipos dramáticos da vegetação e do ciclo vegetal (...). (DURAND, 2002, p.259)

Durand também assinala a existência de uma relação entre alimentos e sexualidade:

Desde Freud sabemos explicitamente que a gulodice se encontra ligada à sexualidade, o oral sendo o emblema regressivo do sexual. Percebemos na história de Eva mordendo a maçã imagens que reenviam para os símbolos do animal devorador, mas igualmente a interpretamos considerando a ligação freudiana entre o ventre sexual e o ventre digestivo. (...) (DURAND, 2002, p.117).

No processo de digestão, o intestino é associado a abismo, e também a esgoto, assim como a "labirinto infernal em miniatura" (DURAND, 2002, p.120). Sendo que outro símbolo de intimidade consiste no ouro do alquimista, concebido como a substância oculta ou a essência das coisas, muitas vezes também é associado ao referido processo: "Nem tudo o que brilha é ouro. A substância do precioso metal é simbólica de todas as intimidades. (...). A retorta digere e o ouro é um precioso excremento" (DURAND, 2002, p.262).

Ainda com relação à alquimia, interessante assinalar que a mesma não apenas simboliza o regime noturno pelos aspectos de descida e de intimidade que representa, mas também veicula significações ascensionais relativos ao regime diurno do imaginário, como bem explicita Durand a seguir, caracterizando a alquimia como um saber e uma prática que lida com ambas simbologias de modo integrado:

\footnotetext{
A sublimação alquímica, realizando totalmente uma completa filosofia do ciclo, acede assim a uma simbólica ascensional que, ultrapassando as premissas involutivas (...), faz da alquimia uma simbólica completa, funcionando nos dois regimes da imagem (DURAND, 2002, p.228).
}

A natureza em seu aspecto maternal está representada também nas simbologias terrestres e aquáticas, compreendidas como a matéria primordial, no "arquétipo da descida e do retorno às fontes originais da felicidade" (DURAND, 2002, p.225), remetendo assim ao simbolismo da intimidade. Sendo que, enquanto a água seria a mãe da vida de modo geral, a terra seria a mãe dos seres terrestres: 
(...) existiria uma diferença sutil entre a maternidade das águas e a da terra. As águas encontrar-se-iam 'no princípio e no fim dos acontecimentos cósmicos', enquanto a terra estaria 'na origem e no fim de qualquer vida'. As águas seriam, assim, as mães do mundo, enquanto a terra seria a mãe dos seres vivos e dos homens (DURAND, 2002, p.230).

Primitivamente, a terra, tal como a água, é a primordial matéria do mistério, a que é penetrada, que é escavada e que se diferencia simplesmente por uma resistência maior à penetração. (...). Essa crença na divina maternidade da terra é certamente uma das mais antigas; de qualquer modo, uma vez consolidada pelos mitos agrários, é uma das mais estáveis. (...). O casal divino céu-terra é (...) um leitmotiv da mitologia universal. (...). Em todos esses mitos [do casal céu/-terra], a terra desempenha um papel passivo, embora primordial (DURAND, 2002, p.230).

Um sentido atribuído à terra refere-se à intimidade no enterramento no momento da morte (isomorfismo sepulcro-berço): "A terra torna-se berço mágico e benfazejo porque é o lugar do último repouso" (DURAND, 2002, p. 237). Em outro sentido, é a terra que gera e guarda minérios preciosos e que amadurecem lentamente, sendo que a alquimia visa acelerar esse processo artificialmente: “(...) as crenças alquímicas e mineralógicas universais afirmam que a terra é a mãe das pedras preciosas, regaço onde o cristal amadurece em diamante. (...)." (DURAND, 2002, p.231).

A água, por sua vez, em diversas culturas aparece como a matéria primordial, principalmente a marinha, como o primeiro berço do surgimento da vida. Sendo que o simbolismo da serpente, além de vinculada à terra em diversos mitos, também apresenta relação com a água, pela semelhança do próprio movimento corporal com a fluidez do elemento aquático: "as ondulações do seu corpo simbolizam as águas cósmicas (...)." (DURAND, 2002, p.317).

\section{Resultados}

Tendo como fundo o arcabouço teórico apresentado, explicitando as duas grandes categorias simbólicas concernentes aos regimes diurno e noturno das imagens na perspectiva durandiana, pode-se perceber a presença de ambas nas obras escolhidas, cujas análises são apresentadas a seguir. 


\subsection{Os simbolismos diurnos nas referidas obras de Arcimboldo}

A recorrência da representação de cabeças de frente ou de perfil nas obras analisadas, tanto de animais como humanas que formam o todo das imagens ambivalentes, permite remeter ao esquema ascensional e à imagem do herói, bem como também a uma ênfase na consciência racional e, portanto, ao regime diurno das imagens, indicando uma ênfase na racionalidade, e no que é considerado masculino.

No caso do retrato pintado por Arcimboldo (figura 5), o imperador Rodolfo II é equiparado ao deus romano Vertumnus, o deus das estações, apontando para a divinização do lugar ocupado pelo governante imperial, dando visibilidade, ao arquétipo do monarca poderoso e dominador (KAUFFMANN, 2009; KRIEGESKORTE, 2006). Assim, o imperador representado é equiparado a um deus romano, assinalando para a divinização do lugar ocupado pelo governante imperial, indicando o lugar do masculino como o do soberano paternal e dominador.

Com relação à significação do olho, o único quadro analisado que olha para a frente, parecendo fitar o observador, é "Vertumnus", enquanto os demais estão de perfil, parecendo contemplar o horizonte. Assim, o olho do rei pode ser percebido como assimilado à ideia do olho onisciente de Deus, remetendo à ideia de transcendência divina.

Sobre as bocas dentadas (abertas ou entreabertas, e em alguns casos aparecem os dentes) aparecem em "Ar", "Água" e "Vertumnus" (figuras 3, 4 e 5), pode-se presumir um certo sentido de violência selvagem, ferocidade animal, como também pode-se associar ao temor do tempo fugaz e destruidor (ao "terror diante da mudança da morte devoradora" (Durand, 2002, p.89)), em que o tempo é, no regime diurno, considerado numa perspectiva linear de não retorno, e nesse sentido, o destino é concebido como fatalidade. Interessante que Vertumnus, de Arcimboldo, parece ser um deus pacífico, antes que guerreiro, apesar da boca encarnada e dentada.

Estabelecendo uma relação entre as simbologias do monarca e do céu, a partir da leitura realizada da obra de Durand, é relacionar as obras "Vertumnus" e "Ar" (figuras 5 e 3), esta última simbolizando o céu e a altitude do poder representada pelas aves, que em sua maioria são capazes de alçar voo. Tal associação, no contexto desta pesquisa, conduz à possibilidade de se estabelecer 
tal relação, as quais num primeiro momento não parecem possuir alguma relação entre si. Assim, "Ar" (figura 3) poderia estar representando, não propriamente o elemento aéreo, e sim o céu e a altitude do poder representada por aves das mais variadas espécies.

Um outro aspecto do simbolismo do monarca celestial refere-se a que esse lugar não é solitário - ideia que pode estar representada na multidão de pássaros na cabeça em "Ar" -, e nem dessexualizado, mantendo uma relação muito próxima com a terra. Sendo que tal simbologia da união entre o rei celestial e a deusa-mãe terra está presente em diversos mitos, nos quais o próprio soberano pode apropriar-se do elemento simbólico feminino da fertilidade, como o "Esposo celeste, companheiro fecundador da deusa mãe" (DURAND, 2002, p.138).

Em "Fogo", além de ouro, riquezas advindas do mundo mineral, também aparecem armas de fogo, remetendo à simbologia do herói (DURAND, 2002, p.161), permitindo relacionar "Vertumnus" e "Fogo" (figuras 5 e 2). Além disso, a presença de metal, e mais especificamente do ouro, permite estabelecer associações com a ideia de purificação pela prática da alquimia. Também em "Fogo", a incineração na cabeça da figura permite remeter, conforme visto, a um sentido de transcendência e de imortalidade da alma (DURAND, 2002, p.173). Sendo que também se pode identificar o simbolismo da luz e da chama como simbolizando poder (DURAND, 2002).

Em "Terra" pode-se notar a coexistência de animais selvagens e domesticados, convivendo próximos uns aos outros no limitado espaço representado que forma a referida cabeça composta, podendo-se pensar em uma utopia, como pode ser vista em algumas crenças religiosas sobre a vinda de uma futura idade de ouro de convivência pacífica entre todos os seres.

Também em "Terra" (figura 1), a simbologia da caça como troféu é explicitada na pele do leão que aparece no ombro da figura, simbolizando assim virilidade e desfeminização, e apresentando também a simbologia dos chifres coroando a cabeça, o que por sua vez simboliza força e poder apropriada dos animais caçados. Sendo que, apesar do leão aparecer em diversas mitologias como um animal terrível, em "Terra" tal animal aparece morto, o que também pode levar a pensar que tal ameaça foi extirpada na referida representação imagética de Arcimboldo.

Principalmente as cabeças compostas em "Ar", "Fogo" e "Terra" permitem identificar tais simbologias diurnas, enquanto os dois primeiros apenas aspectos 
diurnos e valores do patriarcado. Portanto, considerando o exposto até o momento, "Ar" representaria apenas elementos diurnos.

\subsection{Os simbolismos noturnos nas referidas obras de Arcimboldo}

Com relação ao regime noturno do imaginário, um elemento comum nas cinco obras consiste no fundo escuro, possibilitando remeter ao imaginário da noite, e assim enfatizar um aspecto geral sombrio, misterioso, caótico e até mesmo aterrorizante, associado a uma imaginação de trevas nefastas relacionada ao passado remoto da humanidade.

Também quanto ao aspecto tenebroso, as cabeças compostas podem ser concebidas como monstruosas, sobre o que Gilbert Durand afirma tratar-se de símbolo de totalização, e também como um símbolo cíclico. A abundância decorrente da junção de elementos díspares e muitas vezes opostos representa pluralidade e apontam para o maravilhamento que os contemporâneos do artista sentiam frente ao bizarro, justamente em virtude do sentido totalizante desse tipo de representação.

Esta noção de pluralidade muitas vezes remete também à abundância, podendo ser percebida nas cinco obras: de animais em "Ar", "Terra" e "Água" (figuras 3,1 e 4); de riqueza e armamento bélico em "Fogo" (figura 2), e de diversos tipos de vegetais em "Vertumnus" (figura 5).

Sendo que, apesar das diferenças individuais com relação aos sentidos pessoais atribuídos às obras pictóricas, pode-se dizer que o sentimento de pavor pode ser identificado facilmente em "Água" (figura 4), por suas tonalidades escuras e sombrias que predominam, apesar de um contraponto presente em alguns tons vibrantes, com destaque para o vermelho, no aspecto assustador de vários de seus animais representados, entre os quais aparecem os olhos arregalados, e principalmente com relação ao seu aspecto geral 'inquietante'. Enquanto tal aspecto terrível de "Água" (figura 4) está presente em animais ferozes e por isso amedrontadores, também aparece nos animais ferozes em "Terra" (figura 1).

Em "Água” (figura 4), destacam-se imagens de serpentes, de peixes e de conchas, remetendo à simbologia da intimidade, com as simbologias de engolimento, esconderijo, refúgio e repouso.

Também "Vertumnus" (figura 5) apresenta símbolos de intimidade e profundidade, como na vinha, trigo, milho, e outros grãos, relacionados ao arquétipo 
do alimento primordial.

Outro símbolo de intimidade consiste no ouro do alquimista, concebido como a substância oculta ou essência das coisas, o qual aparece em "Fogo" (figura 2).

Embora a árvore não apareça nessas obras, pode-se perceber sua presença indiretamente em "Fogo" (na madeira sendo queimada) e em "Vertumnus" (nos frutos e flores provenientes de árvores) (figuras 2 e 5). Assim, a árvore aparece presente nessas obras, ao menos como indício pela representação de partes suas.

Sendo que em diversas figuras representadas é possível perceber, em virtude dos seus simbolismos, descritos anteriormente, significações referentes a renovação, transformação e regeneração cíclicas da natureza, bem como também as noções de fecundidade, abundância e ambiguidade.

É possível que a ideia de desejar sobreviver ao tempo tenha estado presente em "Vertumnus" (figura 5) e nas demais obras analisadas ao considerar-se que buscavam enaltecer o imperador e vaticinar poder eterno à linhagem dos Habsburgo. Possivelmente seja esse o motivo de Rodolfo II ter sido representado por vegetais e não haja a presença de nenhum animal nesse seu retrato - pois animais poderiam trazer a ideia de queda e impureza, embora estejam presentes nas demais obras, que não se referem explicitamente ao imperador - bem como a proliferação de símbolos como vegetais e serpentes.

Em síntese, enquanto "Ar" e "Fogo" (figuras 3 e 2) representariam o regime diurno e o patriarcado, "Terra" e "Água" (figuras 1 e 4), representariam predominantemente o regime noturno das imagens e o matriarcado, sendo que em "Vertumnus" (figura 5) também predominaria o matriarcado. Portanto, considerando o exposto, as duas primeiras obras representariam principalmente elementos diurnos, enquanto as duas últimas simbolizariam predominantemente o regime noturno das imagens. Inclusive, as obras referentes aos quatro elementos poderiam constituir dois pares, um de cada uma dessas duas categorias. E considerando-se as direções dos perfis, tais casais formados seriam: "Ar"-“Água”; e "Fogo”-“Terra”. E assim, o esquema da ascensão ("Ar") se opõe ou se une ao da profundidade (“Água”), e o esquema da luz (“Fogo") com o das trevas (“Terra”). 


\title{
5 Considerações finais
}

Embora a perspectiva simbólica permita diversas possibilidades de significação, a partir das simbologias representadas pictoricamente e identificadas conforme as grandes categorias do imaginário apresentadas por Durand (2002), foi possível realizar a seguinte leitura. A de que tais obras simbolizam um imperador poderoso e paternal, purificado, comparado a um deus romano, cujo poder provém de força e inteligência aumentadas pelo poder mágico advindo de práticas alquímicas. Tal poder evidencia-se pela capacidade de transformação e regeneração decorrente do domínio das forças da natureza. Além disso, os simbolismos indicam abundância e união dos chamados princípios masculino e feminino, num resultado andrógino que simboliza completude e perfeição. Ainda, é possível afirmar que esta leitura não contradiz a interpretação de que tais obras visavam glorificar o imperador, cujo domínio sobre os elementos the conferiria poder eterno (KAUFFMAN, 2009; KRIEGESKORTE, 2006). Como na seguinte passagem a respeito dessa leitura:

\begin{abstract}
O mundo é composto por elementos, e quem quer que governe os elementos dominará o mundo, portanto, o Imperador irá esmagar o poder dos Turcos. As quatro estações voltam todos os anos, simbolizando assim a ordem eterna da natureza bem como a ideia de que os Habsburgos reinarão para sempre (...). (KRIEGESKORTE, 2006, p.50).
\end{abstract}

Além disso, a presença das duas grandes categorias de regimes do imaginário permite identificar equilíbrio e convivência de opostos, com forte ênfase para o regime noturno, considerado como não excludente ao tolerar a presença dos símbolos diurnos.

Essa variedade de significados encontrados nessas obras e que aparecem convivendo no mesmo espaço pictórico, sem uma predominância definitiva de uma sobre as demais, ou de um regime das imagens sobre o outro, pode parecer contraditório quando considerada da perspectiva da cultura atual. No entanto, tal resultado abrangente era aceito no século XVI, quando a realidade era vista como complexa, plural e contraditória, e a imaginação voltava-se para o fantástico, monstruoso, paradoxal, mitológico e misterioso (KAUFFMANN, 2009; HOCKE, 2005; HAUSER, 2007). Assim, tal resultado é consoante com o imaginário renascentista, marcado pela mitologia e busca de relações e correspondências entre os diferentes aspectos da realidade.

Além desse aspecto da oposição de contrários, pode-se perceber também 
nessas obras de Arcimboldo, a ambivalência, pois não há uma única forma de vê-las em virtude de que ao mesmo tempo há duas possibilidades de leitura na obra, demandando que o espectador escolha se prefere focar as partes, e assim ter uma visão de multiplicidade formada por muitos elementos facilmente identificáveis e claramente definidos, ou se prefere privilegiar uma visão unitária da obra, também identificável dessa configuração (REMSHARDT, 2004). O que permite perceber uma visão da realidade como contraditória, cujos opostos são inconciliáveis, embora paradoxalmente possam dividir o mesmo espaço, buscando apreender um todo formado pela diferença e diversidade. E que, portanto, era esperado que as obras desse período apresentassem contradições, paradoxos, antíteses e, em decorrência disso, incoerências e conflitos, aos quais não se visava resolução, sob pena de exclusão de uma parte desse todo, o que por sua vez conduziria a um conhecimento incompleto.

Assim, pode-se perceber um jogo de ideias, constituindo assim a obra como um enigma a ser decifrado que satisfaz o intelectualismo do estilo maneirista da época. O fato de tratar-se de imagens formadas por relações insólitas e muitas vezes inesperadas entre os objetos representados para formar um rosto "humano", permitem perceber o gosto da época pelo estranho, diferente, até mesmo bizarro, ressaltando a ideia de irrealidade, a qual, por sua vez, está ao mesmo tempo representada nas figuras de animais, objetos ou vegetais pintados detalhadamente, de forma bastante realista, novamente unindo opostos em uma mesma obra.

Tal inventividade foi acolhida efusivamente também na atualidade, quando tais obras recebem atenção novamente num momento em que predomina a simbologia diurna, enfatizando a razão e uma relação com a natureza de desconexão, domínio e desvendamento de seus mistérios, com ampla proliferação de imagens visuais cuja leitura imagética atual possui características diferenciadas, realizada de forma acelerada, irrefletida e superficial (HARVEY, 1993; JAMESON, 1997; LYOTARD, 1998; GIDDENS, 1991). E assim, em contraposição à época de Arcimboldo, nos séculos $X X$ e $X X I$ a imaginação direciona-se preferentemente para o lúdico, desconexo, fragmentado, efêmero, especializado e simplificado (HARVEY, 1993; JAMESON, 1997).

Assim, aponta-se para uma diferença cultural no sentido de que, enquanto tais obras demonstravam um interesse em relacionar elementos diferentes e unir os separados, na época atual, ao contrário, predomina o interesse em separar o que 
estava unido. ${ }^{7} \mathrm{E}$ num certo sentido, os arquétipos representados pelos diversos símbolos presentes nas obras, fazem parte de um imaginário que não pertence exclusivamente a uma época, constituindo-se como atemporal.

7 Tal afirmação foi realizada a partir da apropriação dos conceitos, respectivamente, "concordia discors" e "discordia concors", de Gustav R. Hocke (2005).

Cad. de Pesq. Interdisc. em Ci-s. Hum-s., Florianópolis, v.13, n.102, p.224-249 jan/jun 2012 


\section{REFERÊNCIAS}

DURAND, Gilbert. O retorno do mito: introdução à mitodologia. Mitos e sociedades. Revista FAMECOS. Porto Alegre, n. 23, abril 2004, pp. 07-22.

DURAND, Gilbert. As estruturas antropológicas do imaginário. $3^{\mathrm{a}}$ ed. São Paulo: Martins Fontes, 2002.

DURAND, Gilbert. La imaginación simbólica. Buenos Aires: Amorrortu editores, 1968.

GIDDENS, Anthony. As conseqüências da modernidade. $2^{\mathrm{a}}$ ed. São Paulo: ed. da UNESP, 1991.

HARVEY, David. Condição pós-moderna: uma pesquisa sobre as origens da mudança cultural. São Paulo: Edições Loyola, 1993.

HAUSER, Arnold. Maneirismo. $2^{\mathrm{a}}$ ed. São Paulo: Perspectiva, 2007.

HILLMAN, James. O Mito da análise: três ensaios de psicologia arquetípica. Rio de Janeiro: Paz e Terra, 1984.

HOCKE, Gustav René. Maneirismo: o mundo como labirinto. $3^{\text {a }}$ ed. São Paulo: Perspectiva, 2005.

JAMESON, F. Pós-modernismo: a lógica cultural do capitalismo tardio. $2^{\mathrm{a}}$ ed. São Paulo: Ática, 1997.

JUNG, Carl Gustav. Estudos sobre psicologia analítica: psicologia do inconsciente, o Eu e o inconsciente. $2^{\mathrm{a}}$ ed. Petrópolis: Vozes. (Obras Completas de C. G. Jung, v. 7), 1981.

JUNG, Carl Gustav. El hombre y sus símbolos. Madrid: Aguilar, 1995.

LYOTARD, J. F. A condição pós-moderna. $5^{\text {a }}$ ed. Rio de Janeiro: José Olympio, 1998. 
KAUFFMANN, Thomas DaCosta. Arcimboldo: visual jokes, natural history, and stilllife painting. Chicago and London: University of Chicago, 2009.

KRIEGESKORTE, Werner. Giuseppe Arcimboldo, 1527-1593. Lisboa: Taschen, 2006.

REMSHARDT, Ralf E. Staying the savage god: the grotesque in performance. Illinois: Southern Illinois University, 2004.

WEB GALLERY OF ART. Arcimboldo. Disponível em: <http://www.wga.hu/framese.html?/html/a/arcimbol>. Acesso em: 24 mar. 2011.

Artigo:

Recebido em: 16/10/2011

Aceito em: 22/05/2012 